\author{
MAGDALENA KUBA \\ ORCID: 0000-0002-9090-4737 \\ Uniwersytet Łódzki \\ Akademia Leona Koźmińskiego w Warszawie
}

\title{
POJECCIE ADMINISTRATORA I POJECCIE PRACODAWCY W STRUKTURACH PAŃSTWOWEJ INSPEKCJI PRACY
}

\begin{abstract}
Abstrakt: Opracowanie dotyczy problematyki administratora w strukturach Państwowej Inspekcji Pracy. Przedmiotem analizy jest status pracodawcy jako administratora danych osobowych pracowników Państwowej Inspekcji Pracy. Autorka podejmuje również próbę zidentyfikowania innych administratorów danych osobowych przetwarzanych w kontekście działalności Państwowej Inspekcji Pracy, wskazując na pewne niejasności wyłaniające się na tle analizy aktualnych regulacji prawnych.
\end{abstract}

Słowa kluczowe: dane osobowe, rozporządzenie 2016/679, administrator, pracodawca, Państwowa Inspekcja Pracy

\section{UWAGI WSTĘPNE}

Złożony charakter powiązań występujących w sektorze publicznym nastręcza trudności we właściwym zdefiniowaniu ról w ramach realizowanych procesów przetwarzania danych osobowych, w tym także w ustaleniu, który podmiot posiada status administratora danych osobowych. Pomocne może okazać się więc wyznaczenie administratora w prawie krajowym. W świetle art. 4 pkt 7 rozporządzenia Parlamentu Europejskiego i Rady (UE) 2016/679 z dnia 27 kwietnia 2016 roku w sprawie ochrony osób fizycznych w związku z przetwarzaniem danych osobowych i w sprawie swobodnego przepływu takich danych oraz uchylenia dyrektywy 95/46/WE (ogólne rozporządzenie o ochronie danych) ${ }^{1}$ ustawodawca krajowy jest uprawniony do wskazania w przepisach prawa administratora lub kryteriów jego wyznaczenia, o ile jednocześnie określi on cele i sposoby przetwarzania danych osobowych.

Problematykę tę dodatkowo komplikuje okoliczność, że przyjęta w polskim prawie pracy definicja legalna pracodawcy oparta jest na tak zwanej koncepcji za-

1 Dz.Urz. UE L 119 z 4 maja 2016 roku; dalej: rozporządzenie 2016/679. 
rządczej, co w przełożeniu na relacje prawno-organizacyjne występujące w sektorze publicznym powoduje, że określony podmiot pełni rolę administratora danych osobowych pracowników (jako pracodawca), ale niekoniecznie posiada on status administratora $w$ innych obszarach przetwarzania danych osobowych, a w rezultacie pracownicy zatrudnieni przez ten podmiot przetwarzają - w toku wykonywania obowiązków służbowych - dane osobowe w imieniu innego podmiotu. $\mathrm{Na}$ tym tle powstaje wiele wątpliwości trudnych do jednoznacznego rozstrzygnięcia w obecnym stanie prawnym. Doskonałym tego przykładem jest Państwowa Inspekcja Pracy, której status prawny określa ustawa z dnia 13 kwietnia 2007 roku $^{2}$.

\section{POJĘCIE PRACODAWCY W SEKTORZE PUBLICZNYM}

Definicja legalna pracodawcy w jej aktualnym brzmieniu jest efektem nowelizacji kodeksu pracy ${ }^{3}$ dokonanej na mocy ustawy z dnia 2 lutego 1996 roku o zmianie ustawy - Kodeks pracy oraz o zmianie niektórych ustaw ${ }^{4}$. Na gruncie obowiązującego wcześniej art. 3 k.p. przyjęto, że podmiotem zatrudniającym pracowników jest zakład pracy, przy czym zdefiniowano go jako jednostkę organizacyjną zatrudniającą pracowników, choćby nie posiadała ona osobowości prawnej. W ramach przykładowego wyliczenia wskazano, że zakładem pracy jest w szczególności: przedsiębiorstwo państwowe, urząd lub inna państwowa jednostka organizacyjna, spółdzielnia, organizacja społeczna. Dokonane w Polsce zmiany ustrojowe zaowocowały również zmianą nazwy podmiotu zatrudniającego pracowników. I tak, w świetle aktualnie obowiązującego art. 3 k.p., podmiotem tym jest pracodawca, przy czym w dalszym ciągu może nim być jednostka organizacyjna (również taka, która nie posiada osobowości prawnej), a ponadto osoba fizyczna. Kryterium decydującym o posiadaniu statusu pracodawcy jest w obydwu przypadkach (jednostki organizacyjnej i osoby fizycznej) zatrudnianie pracowników. Mimo literalnego brzmienia elementu przedmiotowej definicji odnoszącego się do zatrudniania ,pracowników”, należy podzielić prezentowany w doktrynie prawa pracy pogląd, że pracodawcą jest osoba fizyczna lub jednostka organizacyjna, która zatrudnia co najmniej jednego pracownika ${ }^{5}$.

Zawarta w art. 3 k.p. definicja pracodawcy oparta jest na koncepcji zarządczej, zgodnie z którą pracodawcą jest ten podmiot, który zarządza majątkiem i innymi zasobami w danej organizacji ${ }^{6}$. Teoria ta przeciwstawiana jest koncepcji właści-

2 Tekst jedn. Dz.U. z 2019 r. poz. 1251; dalej: u.p.i.p.

3 Ustawa z dnia 26 czerwca 1974 roku - Kodeks pracy, tekst jedn. Dz.U. z 2020 r. poz. 1320; dalej: k.p.

4 Dz.U. Nr 24, poz. 110.

5 Zob. K.W. Baran, [w:] Kodeks pracy. Komentarz, t. 1, red. K.W. Baran, Warszawa 2020, s. 53.

${ }^{6}$ Zob. między innymi ibidem, s. 55. 
cielskiej pracodawcy, wedle której to właściciel majątku jest pracodawcą ${ }^{7}$. Przyjęta w polskim prawie pracy teoria pracodawcy jest poddawana krytyce. W szczególności podnosi się, że może ona wpływać niekorzystnie na bezpieczeństwo obrotu prawnego, skoro status pracodawcy (zwłaszcza tak zwanego pracodawcy wewnętrznego ${ }^{8}$ ) może być oderwany od statusu właściciela ${ }^{9}$. Okoliczność ta nie pozostaje bez znaczenia w kontekście ustalania tego, który podmiot pełni rolę administratora.

Mając na względzie teorię zarządczą pracodawcy, przyjmuje się, że podmiotem zatrudniającym pracowników sektora publicznego jest odpowiednia jednostka organizacyjna (nie będąca osobą prawną). Nie jest nim zatem ani Skarb Państwa czy — w przypadku samorządu terytorialnego — gmina, powiat lub województwo, ani też organ osoby prawnej, na przykład wójt (burmistrz, prezydent miasta) jako organ wykonawczy gminy czy rada gminy (miasta) jako organ stanowiący gminy. Potwierdza to zarówno doktryna prawa pracy, jak i liczne w tym zakresie orzecznictwo sądowe ${ }^{10}$. Przykładowo pracodawcą sędziego jest sąd jako jednostka organizacyjna, mimo że sędzia orzeka w imieniu Rzeczypospolitej Polskiej, a zgodnie $z$ Konstytucją $\mathrm{RP}^{11}$ powołania na stanowisko sędziego dokonuje Prezydent RP. Z kolei w przypadku pracowników samorządowych przymiot pracodawcy posiadają jednostki wskazane w art. 2 ustawy z dnia 21 listopada 2008 roku o pracownikach samorządowych ${ }^{12}$, czyli między innymi urząd marszałkowski, starostwo powiatowe oraz urząd gminy, a także odpowiednie jednostki organizacyjne (województwa, powiatu, gminy). Jednocześnie w art. 7 u.p.s. ustawodawca przesądza o tym, kto realizuje czynności z zakresu prawa pracy za jednostki wymienione w art. 2 u.p.s., a są to między innymi marszałek województwa, starosta oraz wójt, burmistrz, prezydent miasta, jak również kierownik danej jednostki organizacyjnej. Należy zatem przyjąć, że jednostki określone w art. 2 u.p.s. mają status pracodawcy w rozumieniu art. 3 k.p., zaś podmioty wymienione w art. 7 u.p.s. reprezentują pracodawcę jedynie w zakresie czynności z zakresu prawa pracy zgodnie $\mathrm{z}$ art. $3^{1} \S 1 \mathrm{k} . \mathrm{p}$. W świetle tej ostatniej regulacji za pracodawcę będącego jednostką organizacyjną czynności w sprawach z zakresu prawa pracy dokonuje osoba lub organ zarządzający tą jednostką (lub inna wyznaczona do tego osoba). W gruncie rzeczy więc art. 7 u.p.s. konkretyzuje reprezentację pracodawcy

7 Szerzej zob. Z. Hajn, Pracodawca i zaktad pracy, „Przegląd Sądowy” 1995, nr 6, s. 3 n.

$8 \mathrm{~W}$ ten sposób określa się pracodawcę, który jest wewnętrzną jednostką organizacyjną osoby prawnej.

9 Zob. Z. Hajn, Koncepcja pracodawcy w powszechnym prawie pracy i szczególnym prawie pracy sfery budżetowej, [w:] Powszechne a szczególne prawo pracy, red. L. Florek, Warszawa 2016, s. 105 n.

10 Zob. między innymi W. Muszalski, [w:] Kodeks pracy. Komentarz, red. W. Muszalski, Warszawa 2015, s. 14, z cytowanym tam orzecznictwem.

${ }^{11}$ Konstytucja Rzeczypospolitej Polskiej z dnia 2 kwietnia 1997 roku, Dz.U. Nr 78, poz. 483 ze zm.

12 Tekst jedn. Dz.U. z 2019 r. poz. 1282; dalej: u.p.s. 
w rozumieniu art. $3^{1} \S 1$ k.p., nie stanowi zaś, że wymienione podmioty pełnią funkcję pracodawcy. W przypadku zresztą takich pracowników samorządowych, jak wójt, burmistrz, prezydent miasta, starosta (i inni członkowie zarządu powiatu) oraz marszałek województwa (i inni członkowie zarządu województwa) przepisy art. 8 ust. 1, art. 9 ust. 1 i art. 10 ust. 1 u.p.s. wskazują explicite urząd gminy, starostwo powiatowe oraz urząd marszałkowski jako pracodawców. Nie ma zatem wątpliwości, że przymiot pracodawcy posiadają tutaj odpowiednie jednostki organizacyjne i to im przysługuje zdolność zatrudniania pracowników.

Zaznaczyć wypada, że obok zdolności prawnej w zakresie prawa pracy jednostka organizacyjna musi również dysponować zdolnością sądową i zdolnością procesową. Jest to istotne zwłaszcza w kontekście ochrony praw pracownika i możliwości egzekwowania ich wykonania przez pracodawcę. Jak wynika z art. $64 \S 1^{1}$ oraz art. $65 \S 1$ kodeksu postępowania cywilnego ${ }^{13}$, jednostce organizacyjnej nie będącej osobą prawną, ale posiadającej zdolność prawną (tutaj w zakresie prawa pracy), przysługuje zdolność sądowa oraz zdolność procesowa, przy czym czynności procesowych jednostka ta dokonuje przez swoje organy lub osoby uprawnione do działania w ich imieniu (art. 67 k.p.c.). Jednostki organizacyjne jako pracodawcy w sektorze publicznym dysponują zatem zdolnością sądową i procesową.

\section{PRACODAWCA JAKO ADMINISTRATOR W STRUKTURACH PAŃSTWOWEJ INSPEKCJI PRACY}

Mając na względzie teorię zarządczą pracodawcy, należy przyjąć, że przymiot pracodawcy przysługuje jednostkom organizacyjnym Państwowej Inspekcji Pracy, do których zgodnie z art. 3 ust. 1 u.p.i.p. zalicza się Główny Inspektorat Pracy, okręgowe inspektoraty pracy oraz Ośrodek Szkolenia Państwowej Inspekcji Pracy. Takie też stanowisko zajął Sąd Najwyższy w uchwale z dnia 24 listopada 1992 roku ${ }^{14}$. Wśród pracowników Państwowej Inspekcji Pracy wymienia się: Głównego Inspektora Pracy i jego zastępców, okręgowych inspektorów pracy i ich zastępców, pracowników wykonujących czynności kontrolne oraz pracowników zatrudnionych na innych stanowiskach. Podmiotami zatrudniającymi wspomnianych pracowników są zatem odpowiednio Główny Inspektorat Pracy, okręgowe inspektoraty pracy oraz Ośrodek Szkolenia Państwowej Inspekcji Pracy, przy czym czynności z zakresu prawa pracy wykonuje w zastępstwie tych jednostek osoba, organ lub inna osoba wyznaczona do zarządzania tą jednostką (art. $3^{1} \S 1$ k.p.). Podobnie jak w przypadku pracowników samorządowych ustawodawca wyznacza expressis verbis podmioty dokonujące tych czynności za wskazanych pracodaw-

13 Ustawa z dnia 17 listopada 1964 roku - Kodeks postępowania cywilnego, tekst jedn. Dz.U. z 2020 r. poz. 1575 ze zm.; dalej: k.p.c.

14 I PZP 59/92. 
ców. Zgodnie z art. 18 ust. 6 u.p.i.p. jest to Główny Inspektor Pracy w stosunku do pracowników Głównego Inspektoratu Pracy oraz pracowników nadzorujących lub wykonujących czynności kontrolne (także tych zatrudnionych w okręgowych inspektoratach pracy). Główny Inspektor Pracy może jednak upoważnić okręgowego inspektora pracy do dokonywania czynności z zakresu prawa pracy wobec pracowników okręgowego inspektoratu pracy nadzorujących lub wykonujących czynności kontrolne (art. 18 ust. 7 u.p.i.p.). Co do zasady więc okręgowy inspektor pracy nie wykonuje czynności z zakresu prawa pracy w stosunku do powyższej kategorii pracowników (chyba że zostanie do tego upoważniony przez Głównego Inspektora Pracy), natomiast realizuje te czynności wobec pozostałych pracowników okręgowego inspektoratu pracy (art. 19 ust. 3 u.p.i.p.). Warto ponadto nadmienić, że Główny Inspektor Pracy powołuje i odwołuje określonych pracowników okręgowego inspektoratu pracy (między innymi zastępców okręgowego inspektora pracy) oraz określonych pracowników Ośrodka Szkolenia Państwowej Inspekcji Pracy (między innymi dyrektora i jego zastępców), jak również mianuje pracowników wykonujących czynności kontrolne i rozwiązuje z nimi stosunek pracy (art. 40 ust. 1 oraz art. 41 ust. 2 u.p.i.p.).

Jednostki organizacyjne Państwowej Inspekcji Pracy, to jest Główny Inspektorat Pracy, okręgowe inspektoraty pracy, oraz Ośrodek Szkolenia Państwowej Inspekcji Pracy jako podmioty wyposażone w zdolność do zatrudniania pracowników pełnią jednocześnie funkcję administratora danych osobowych określonych kategorii pracowników Państwowej Inspekcji Pracy. Nie ma bowiem wątpliwości, że to pracodawca jest podmiotem decydującym o celach i sposobach przetwarzania danych osobowych pracowników, a zatem jest administratorem w rozumieniu art. 4 pkt. 7 rozporządzenia 2016/679. Z całą pewnością administrator danych osobowych musi posiadać zdolność prawną, to jest zdolność do ponoszenia odpowiedzialności. Przypomnieć zatem wypada, że pracodawca będący jednostką organizacyjną posiada zdolność sądową, jak również zdolność procesową na gruncie przepisów k.p.c. Co więcej, także ustawa z dnia 30 sierpnia 2002 roku Prawo o postępowaniu przed sądami administracyjnymi ${ }^{15}$ przyznaje zdolność sądową oraz zdolność procesową między innymi państwowym jednostkom organizacyjnym nieposiadającym osobowości prawnej (art. $25 \S 2$, art. $26 \S 1$ ). Zagadnienie to jest istotne zwłaszcza w kontekście ponoszenia przez administratora odpowiedzialności na gruncie przepisów rozporządzenia 2016/679. W tym wypadku odpowiedzialność ta wiąże się z przetwarzaniem danych osobowych pracowników. To pracodawca jest więc odpowiedzialny za przestrzeganie zasad dotyczących przetwarzania tych danych i zobowiązany jest wykazać ich przestrzeganie (art. 5 ust. 2 rozporządzenia 2016/679), mimo że czynności z zakresu prawa pracy wobec niektórych pracowników dokonuje inny podmiot, na przyklad Główny Inspektor

15 Tekst jedn. Dz.U. z 2019 r. poz. 2325 ze zm. 
Pracy w stosunku do pracowników okręgowego inspektoratu pracy będącego administratorem danych osobowych pracowników tego inspektoratu.

Okoliczność ta skłania do rewizji ustaleń dotyczących pracodawcy jako (jedynego) administratora danych osobowych pracowników. Potwierdzają to także niektóre z ostatnich działań legislacyjnych. Mianowicie wprowadzony do ustawy z dnia 27 lipca 2001 roku Prawo o ustroju sądów powszechnych ${ }^{16}$ art. 175a $\S 1$ świadczy o zmianie podejścia do określania roli administratora w kontekście danych osobowych pracowników. Z powyższej regulacji wynika bowiem, że administratorami danych osobowych pracowników sądów są prezesi i dyrektorzy właściwych sądów oraz Minister Sprawiedliwości w zakresie realizowanych zadań. Przypomnieć przy tym trzeba, że pracodawcą tych pracowników jest sąd jako jednostka organizacyjna. Abstrahując od oceny powyższego rozwiązania, należy skonstatować, że dla rozstrzygnięcia przedmiotowej kwestii w kontekście przetwarzania danych osobowych pracowników Państwowej Inspekcji Pracy konieczna może okazać się interwencja ustawodawcy. O ile bowiem jasny jest status pracodawcy w strukturach Państwowej Inspekcji Pracy, o tyle ustalenie tego, czy jest on jedynym administratorem danych osobowych pracowników, nastręcza pewnych trudności.

\section{WIELOŚĆ ADMINISTRATORÓW W STRUKTURACH PAŃSTWOWEJ INSPEKCJI PRACY}

Wątpliwości w powyższym zakresie komplikuje fakt, że w ramach struktur Państwowej Inspekcji Pracy występują — obok jednostek organizacyjnych będących pracodawcami osób zatrudnionych w tych jednostkach — także inne podmioty posiadające określone kompetencje i mogące $\mathrm{w}$ związku z tym pełnić rolę administratorów. Przypomnieć przy tym trzeba, że zgodnie z art. 4 pkt 7 rozporządzenia 2016/679 administratorem może być dowolny podmiot (osoba fizyczna, osoba prawna, organ publiczny, jednostka lub inny podmiot), a zatem w tym kontekście administratorem może być zarówno Państwowa Inspekcja Pracy, jak i jej organy oraz jej jednostki organizacyjne. Jak wskazuje Katarzyna Witkowska-Nowakowska, poza elementem podmiotowym, należy uwzględnić jeszcze dwa inne występujące $w$ definicji legalnej administratora: sposób działania (samodzielnie lub wspólnie z innymi) oraz zakres decyzyjny odróżniający administratora od innych podmiotów (ustalanie celów i sposobów przetwarzania) ${ }^{17}$. W doktrynie zauważa się ponadto, że w przypadku podmiotów sektora publicznego to ustawo-

16 Tekst jedn. Dz.U. z 2020 r. poz. 2072.

17 K. Witkowska-Nowakowska, [w:] RODO. Ogólne rozporządzenie o ochronie danych. Komentarz, red. E. Bielak-Jomaa, D. Lubasz, Warszawa 2018, s. 213 n. 
dawca decyduje o celach, a nawet środkach przetwarzania danych osobowych ${ }^{18}$. Tak też jest w przypadku Państwowej Inspekcji Pracy, zwłaszcza jeśli chodzi o cele przetwarzania.

W świetle art. 1 u.p.i.p. Państwowa Inspekcja Pracy to organ powołany do sprawowania nadzoru i kontroli przestrzegania prawa pracy, przy czym szczegółowe zadania określa art. 10 u.p.i.p. i należą do nich między innymi: kontrola legalności zatrudnienia, innej pracy zarobkowej i wykonywania pracy przez cudzoziemców; wnoszenie powództw o ustalenie istnienia stosunku pracy, a za zgodą osoby zainteresowanej - uczestnictwo w takim postępowaniu przed sądem pracy; ściganie wykroczeń przeciwko prawom pracownika; nadzór i kontrola zapewnienia bezpiecznych i higienicznych warunków pracy. Jednocześnie w art. $11 \mathrm{n}$. u.p.i.p. wskazuje się, że to organy Państwowej Inspekcji Pracy są uprawnione do podjęcia określonych prawem działań między innymi w przypadku stwierdzenia naruszenia przepisów prawa pracy lub przepisów dotyczących legalności zatrudnienia (np. nakazania pracodawcy wypłaty należnego wynagrodzenia za pracę). Na mocy art. 17 u.p.i.p. organami Państwowej Inspekcji Pracy są: Główny Inspektor Pracy (kierujący zgodnie z art. 3 ust. 2 u.p.i.p. Państwową Inspekcją Pracy), okręgowi inspektorzy pracy (kierujący zgodnie z art. 5 ust. 2 u.p.i.p. okręgowymi inspektoratami pracy) oraz inspektorzy pracy działający w ramach właściwości terytorialnej okręgowych inspektoratów pracy. Jednocześnie podkreślić wypada, że osoby pełniące funkcję wzmiankowanych organów posiadają status pracowników, a podmiotem ich zatrudniającym są odpowiednie jednostki organizacyjne Państwowej Inspekcji Pracy, to jest Główny Inspektorat Pracy oraz okręgowe inspektoraty pracy, zaś czynności z zakresu prawa pracy wobec tych pracowników pełnią co do zasady podmioty inne niż jednostki, które ich zatrudniają.

$\mathrm{Z}$ uwagi na fakt, że Państwowa Inspekcja Pracy działa przez swoje organy, a każdy $\mathrm{z}$ nich realizuje przypisane mu kompetencje będące $\mathrm{w}$ istocie emanacją zadań Państwowej Inspekcji Pracy, zasadne byłoby przyjęcie, że to organy pełnią rolę administratorów danych osobowych przetwarzanych w obszarze wykonywania tych zadań, nie zaś Państwowa Inspekcja Pracy. W art. 12 u.p.i.p., odsyłającym do stosowania przepisów Kodeksu postępowania administracyjnego ${ }^{19}$, stanowi się o postępowaniu przed organami Państwowej Inspekcji Pracy, co również może przekonywać do przyjęcia stanowiska, w świetle którego administratorami są Główny Inspektor Pracy oraz okręgowi inspektorzy pracy. Problematyczne byłoby natomiast kwalifikowanie jako administratorów inspektorów pracy (działających w ramach właściwości terytorialnej okręgowych inspektoratów pracy) będących także organami Państwowej Inspekcji Pracy. Oznaczałoby to w istocie, że status administratora posiada każdy pracownik będący inspektorem pracy, który zgodnie

18 P. Litwiński, Ochrona danych osobowych w ogólnym postępowaniu administracyjnym, Warszawa 2009, s. 104 n.

19 Ustawa z dnia 14 czerwca 1960 roku - Kodeks postępowania administracyjnego, tekst jedn. Dz.U. z 2020 r. poz. 256 ze zm. 
z art. 22 ust. 1 u.p.i.p. przeprowadza kontrole w ramach właściwości terytorialnej danego okręgowego inspektoratu pracy.

Istotne dla przedmiotowych rozważań może być również stanowisko Prezesa Urzędu Ochrony Danych Osobowych przyjęte w decyzji z dnia 19 września 2019 roku $^{20}$ adresowanej do Państwowej Inspekcji Pracy. Wprawdzie skarga dotyczyła w tym wypadku Głównego Inspektora Pracy, który wystąpił do urzędu skarbowego z wnioskiem o udostępnienie danych dotyczących pracownika wykonującego czynności kontrolne, Prezes Urzędu Ochrony Danych Osobowych przyjął jednak, że organ ten działał w imieniu Państwowej Inspekcji Pracy jako administratora danych osobowych i to Państwowa Inspekcja Pracy ponosi odpowiedzialność za działania Głównego Inspektora Pracy. Jednocześnie nie kwestionowano odpowiedzialności okręgowego inspektoratu pracy jako jednostki zatrudniającej wspomnianego pracownika i pełniącej w związku z tym także rolę administratora jego danych osobowych. Owszem, przyjęcie stanowiska, zgodnie z którym to Państwowa Inspekcja Pracy jest administratorem, a jej organy wymienione w art. 17 u.p.i.p. korzystają tylko z jej kompetencji, mogłoby pomóc w rozstrzygnięciu licznych wątpliwości natury praktycznej, niemniej wydaje się, że taka koncepcja nie ma wystarczającego umocowania w treści obecnych regulacji prawnych.

\section{UWAGI KOŃCOWE}

Analiza unormowań określających status Państwowej Inspekcji Pracy, jej organów oraz jednostek organizacyjnych prowadzi do wniosku, że interwencja ustawodawcy w oparciu o art. 4 pkt 7 rozporządzenia 2016/679 jest potrzebna dla jednoznacznego ustalenia ról poszczególnych podmiotów w procesach przetwarzania danych osobowych dokonywanych w ramach struktur Państwowej Inspekcji Pracy. Dotyczy to także obszaru przetwarzania danych osobowych pracowników. Wprawdzie okoliczność, że za administratora danych osobowych pracowników uznaje się pracodawcę nie budzi zastrzeżeń, jednak przewidziana w przepisach u.p.i.p. realizacja czynności z zakresu prawa pracy przez podmiot inny niż pracodawca wiąże się z koniecznością przetwarzania przez ten podmiot danych osobowych pracowników i w rezultacie wymaga rozstrzygnięcia charakteru owego przetwarzania. Należałoby zatem oczekiwać wprowadzenia regulacji jednoznacznie określających administratora lub administratorów funkcjonujących w strukturach Państwowej Inspekcji Pracy.

20 Sygn. ZSZZS.440.801.2018. 


\section{THE DEFINITIONS OF “CONTROLLER” AND “EMPLOYER” IN THE NATIONAL LABOUR INSPECTORATE}

\section{Summary}

The article addresses the issue of the controller in the National Labour Inspectorate. It focuses on the status of an employer as a controller regarding the personal data of the National Labour Inspectorate's employees; however, other types of controllers relating to processing personal data in the National Labour Inspectorate are also considered. The analysis covers regulations for personal-data protection, labour law and those related to the legal status of the National Labour Inspectorate.

Keywords: personal data, GDPR, controller, employer, National Labour Inspectorate

\section{BIBLIOGRAFIA}

Baran K.W., [w:] Kodeks pracy. Komentarz, t. 1, red. K.W. Baran, Warszawa 2020.

Hajn Z., Koncepcja pracodawcy w powszechnym prawie pracy i szczególnym prawie pracy sfery budżetowej, [w:] Powszechne a szczególne prawo pracy, red. L. Florek, Warszawa 2016.

Hajn Z., Pracodawca i zakład pracy, „Przegląd Sądowy” 1995, nr 6.

Litwiński P., Ochrona danych osobowych w ogólnym postępowaniu administracyjnym, Warszawa 2009.

Muszalski W., [w:] Kodeks pracy. Komentarz, red. W. Muszalski, Warszawa 2015.

Witkowska-Nowakowska K., [w:] RODO. Ogólne rozporzadzenie o ochronie danych. Komentarz, red. E. Bielak-Jomaa, D. Lubasz, Warszawa 2018. 